\title{
64. UPDATED NANNOFOSSIL STRATIGRAPHY OF THE CIROS-1 CORE FROM MCMURDO SOUND (ROSS SEA) ${ }^{1}$
}

\author{
Wuchang Wei $^{2}$
}

\begin{abstract}
Semiquantitative data of calcareous nannofossil species abundance were collected for 31 samples from 380.00 to $696.61 \mathrm{~m}$ below sea floor (mbsf) in the CIROS-1 core from the western McMurdo Sound (Ross Sea). This core has provided the most complete record of Paleogene glacial history of Antarctica. Only half of the samples yielded calcareous nannofossils and species diversity is generally low. However, several samples contain diverse assemblages and nannofossil zonal markers. Isthmolithus recurvus was found between 406.57 and 681.16 mbsf. This species has an age range of $\sim 35-39 \mathrm{Ma}$ in the mid to high latitudes, as calibrated previously by magnetostratigraphy at a number of DSDP/ODP sites. The interval from 406.57 to $681.16 \mathrm{mbsf}$ can be assigned to the late Eocene-earliest Oligocene ( $\sim 35-39 \mathrm{Ma})$, and the sample at $391.85 \mathrm{mbsf}$, which still contains Reticulofenestra hillae and Reticulofenestra umbilica but does not contain I. recurvus, is identified as early Oligocene age $(\sim 33-34 \mathrm{Ma})$. This represents an age refinement of the previous nannofossil biostratigraphy, where the interval from 385.77 to 690.40 mbsf was dated as middle Eocene-early Oligocene. Comparison of the nannofossil assemblages in the CIROS-1 core with those in a similar glaciomarine sequence recovered in Prydz Bay (East Antarctica) and those at deep-sea ODP Sites 738 and 744, where lowermost Oligocene ice-rafted debris (IRD) were found, suggests that the nannofossils in the CIROS-1 core samples examined are in situ. The semiquantitative nannofossil data also suggest that Isthmolithus recurvus and Reticulofenestra daviesii are most tolerant of cold waters within the late Eocene-early Oligocene nannofloras.
\end{abstract}

\section{INTRODUCTION}

One of the major discoveries of Ocean Drilling Program (ODP) Leg 120 drilling on the central Kerguelen Plateau was the presence of ice-rafted debris (IRD) in lowermost Oligocene nannofossil ooze at Site 748 (Schlich, Wise, et al., 1989; Breza and Wise, this volume). Coincident with the IRD is a sharp positive excursion in foraminifer $\delta^{18} \mathrm{O}$ values at Site 748 and other sites (Zachos et al., this volume). This led Breza and Wise (this volume) to postulate the existence of an earliest Oligocene ice sheet on Antarctic continent.

To evaluate further the Oligocene glacial record of Antarctica, it is useful to reexamine the calcareous nannofossils from a glaciomarine sequence recovered at the CIROS-1 site in the Ross Sea. This glaciomarine sequence has been cited by Breza and Wise (this volume) and others (e.g., Leg 119 Shipboard Scientific Party, 1988; Barrett et al., 1989; Wise et al., in press) as one of the most important evidences for an early Oligocene ice sheet on Antarctica. A discussion on the Eocene glacial record of Antarctica is presented in a companion paper by Wei (this volume), and a synthesis of the Paleogene glacial history of Antarctica is provided by Wise et al. (1991).

CIROS-1 was drilled in western McMurdo Sound in the Ross Sea (Fig. 1) to investigate the Cenozoic glacial and tectonic history of the region. Drilling penetrated $702 \mathrm{~m}$, the deepest ever drilled in Antarctica, and sediments were cored from 26 to $702 \mathrm{~m}$ below seafloor (mbsf), with a core recovery rate of $98 \%$. The upper sequence $(27-366 \mathrm{mbsf})$ is dominated by diamictite beds, which indicate advances of glacier ice over the drill site. The lower sequence (366-702 mbsf) is dominated

\footnotetext{
1 Wise, S. W., Jr., Schlich, R., et al., 1992. Proc. ODP, Sci. Results, 120: College Station, TX (Ocean Drilling Program).

2 Department of Geology, Florida State University, Tallahassee, FL 32306, U.S.A. (present address: Scripps Institution of Oceanography, University of California, San Diego, La Jolla, CA 92093, U.S.A.).
}

by shallow marine mudstones and sandstones. Seven diamictite beds interpreted as waterlain tills are also present in the lower sequence (Hambrey et al., 1989). The lowest of these beds is at about 667 mbsf. Glacier-derived clasts are scattered throughout this lower sequence, indicating glacier calving at sea level for virtually the entire time interval represented by the core. Detailed core log descriptions and environmental interpretations of lithofacies are provided by Robinson et al. (1987), Hambrey et al. (1989), and Barrett et al. (1989).

The upper sequence of the CIROS-1 core was dated as the early Miocene to late Oligocene by diatoms, foraminifers, and magnetostratigraphy (Harwood et al., 1989). The lower sequence was dated as the middle early Oligocene to earliest Oligocene or possibly latest Eocene by compiling biostratigraphic events, with an emphasis on the last occurrence (LO) of the nannofossil Isthmolithus recurvus at $416.84 \mathrm{mbsf}$ and a strontium isotope ratio on shell material at $678.71 \mathrm{mbsf}$ (Harwood et al., 1989). Calcareous nannofossil biostratigraphy for the interval from 385.77 to 690.40 mbsf was given by Edwards and Waghorn (1989). These authors dated the lower sequence as late middle Eocene-earliest Oligocene and suggested a possible middle to late Eocene age for the basal $200-\mathrm{m}$ sequence based on extrapolation of the sedimentation rate from above (see fig. 2 of Edwards and Waghorn, 1989).

Harwood et al. (1989, p. 233) remarked that "in terms of established biostratigraphic age control, calcareous nannofossils probably provided the most accurate control available from the CIROS-1 fossil record." Because calcareous nannofossils are important in dating the CIROS-1 core and because this core is one of the very few available from the extreme high latitudes that contain a considerable record of Paleogene glacial history of Antarctica, it was deemed important to examine the calcareous nannofossils using semiquantitative methods. Comparison of the nannofossil assemblages with those found in a similar glaciomarine sequence recovered from Prydz Bay, East Antarctica (Wei and Thierstein, 1991) could then be made. It was expected that such a study would 


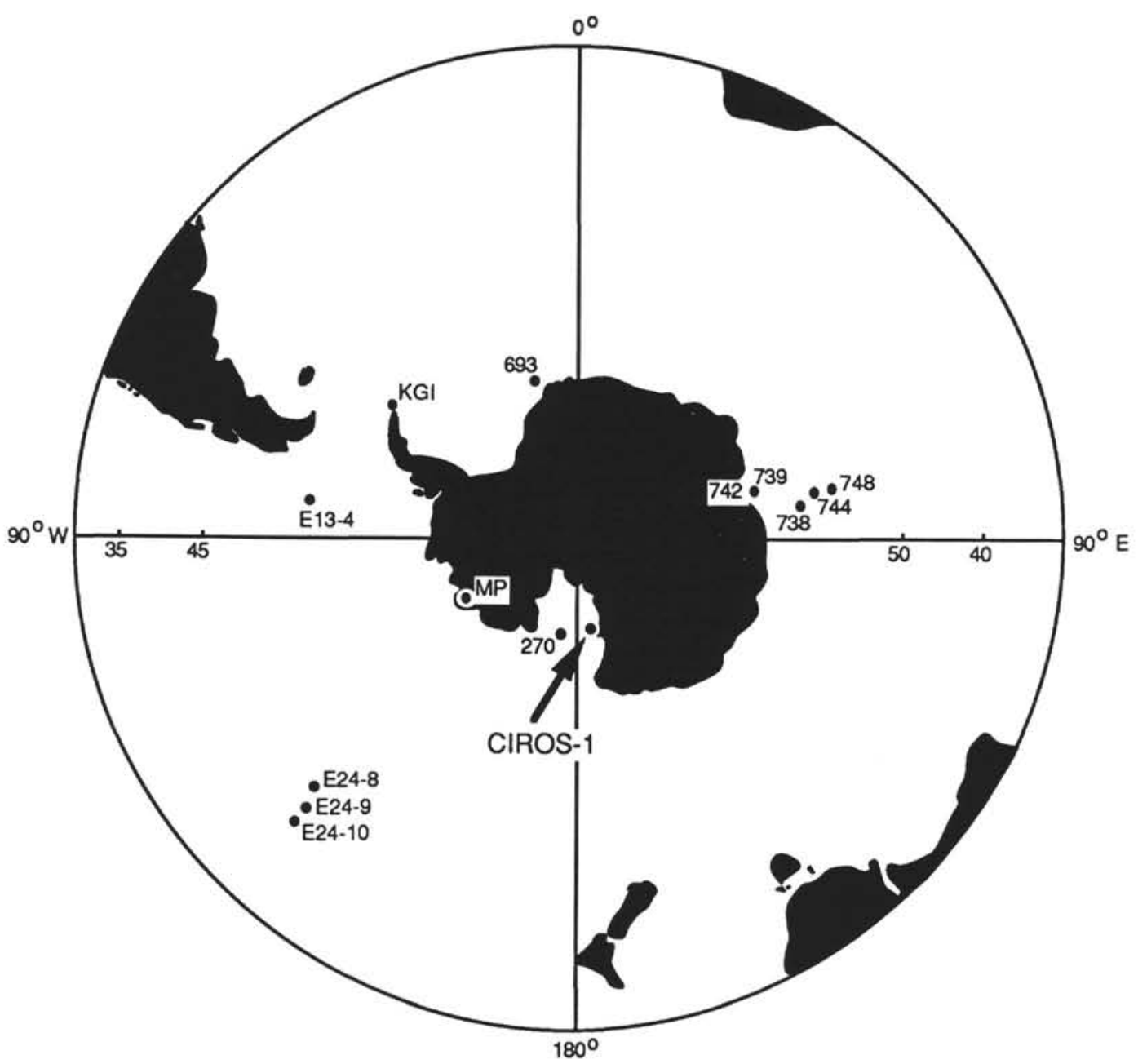

Figure 1. Location map showing the CIROS-1 site and other sites discussed in this paper. E = Eltanin, $\mathrm{KGI}=$ King George Island, and MP $=$ Mt. Petras.

help improve the chronology for the sediments from both the CIROS-1 drill site and Prydz Bay, and would help us to gain some new information on the paleobiogeography and paleoecology of the calcareous nannofossils.

\section{METHODOLOGY}

A total of 31 samples were taken from the interval from 380.00 to 698.61 mbsf in the CIROS-1 core at a sampling frequency of about 1 sample per $10 \mathrm{~m}$. Most of the samples were taken from the mudstones, which represent deeper water facies and which were believed most likely to yield calcareous nannofossils. All the samples were well consolidated, and the surfaces were washed to eliminate any possible contamination. Smear slides were then prepared from the samples and examined in the light microscope at about $\times 650$ magnification.

The relative abundance of calcareous nannofossil species present was estimated using the following criteria: $\mathrm{C}=$ common ( 1 specimen per $2-10$ fields of view); $F=$ few (1 specimen per $11-50$ fields of view $) ; R=$ rare $(1$ specimen per 51-200 fields of view); and B = barren (no specimen was encountered in over 200 fields of view). Preservation of calcareous nannofossil assemblages was recorded as $\mathrm{G}=$ good (little evidence of etching or overgrowth) and $\mathbf{M}=$ moderate (etching or overgrowth is apparent but identification at the species level is generally not impaired).
Species recognized in this study are listed in Table 1 and photographically documented in Plate 1 . Bibliographic references for the calcareous nannofossil species can be found in Perch-Nielsen (1985). The nannofossils are zoned using the high-latitude zonation of Wei and Wise (1990a) (Fig. 2), whose zonal markers have been calibrated with magnetostratigraphy at high-latitude ODP Sites 689, 690 (Wei and Wise, 1990a), 744 (Wei and Thierstein, 1991), and 748 (Wei et al., this volume).

\section{NANNOFOSSIL BIOSTRATIGRAPHY}

The stratigraphic distributions of the calcareous nannofossils are presented in Table 2. The nannofossil data of Edwards and Waghorn (1989) are incorporated in this table to facilitate examination of the nannofossil distribution patterns in the core. Because Edwards and Waghorn (1989) recorded only presence/absence data rather than relative species abundance, their records of "presence" are indicated by an X in the table. The Reticulofenestra callidalR. daviesii, Reticulofenestra sp. cf. $R$. danica, and Reticulofenestra scrippsae they recorded are quite likely to be Reticulofenestra daviesii based on my examination of the samples from this core and samples from Prydz Bay and other southern high-latitude sites. Reticulofenestra daviesii in the CIROS-1 core exhibits various degrees of overgrowth, and when heavily overgrown, the species may resemble $R$. scrippsae. Consequently, the pres- 
Table 1. Calcareous nannofossil species recognized in the CIROS-1 core.

\begin{tabular}{ll}
\hline \multicolumn{1}{c}{ Species } & Plate and figure number \\
\hline $\begin{array}{l}\text { Braarudosphaera bigelowii (Gran and Braarud, 1953) Deflandre, 1967 } \\
\text { Chiasmolithus altus Bukry and Percival, 1971 }\end{array}$ & Plate 1, Figs. 8-10 \\
$\begin{array}{l}\text { Chiasmolithus oamaruensis (Deflandre, 1954) Hay, Mohler and Wade, 1966 } \\
\text { Coccolithus pelagicus (Wallich, 1877) Schiller, 1930 }\end{array}$ & Plate 1, Fig. 1 \\
$\begin{array}{l}\text { Cyclicargolithus floridanus (Roth and Hay, 1967) Bukry, 1971 } \\
\text { Isthmolithus recurvus } \text { Deflandre, 1954 }\end{array}$ & Plate 1, Figs. 17 and 18 \\
$\begin{array}{l}\text { Lithostromation simplex (Klump, 1953) Bybell, 1975 } \\
\text { Reticulofenestra bisecta (Hay, Mohler and Wade, 1966) Roth, 1970 } \\
\text { Reticulofenestra daviesii (Haq, 1968) Haq, 1970 } \\
\text { Reticulofenestra hillae Bukry and Percival, 1971 }\end{array}$ & Plate 1, Figs. 11-16 \\
Reticulofenestra umbilica (Levin, 1865) Martini and Ritzkowski, 1968 & Plate 1, Figs. 6 and 7 \\
\hline
\end{tabular}

Note: Plate and figures numbers refer to illustrations in this paper.

ence data for the above taxa recorded by Edwards and Waghorn (1989) have been credited to $R$. daviesii in Table 2.

Sample 380.00 contains Chiasmolithus altus and Reticulofenestra daviesii, both of which constrain the age to Oligocene or older. Sample 391.85 yielded 10 nannofossil species, a fairly diverse assemblage. The most age-diagnostic species in this sample are Chiasmolithus oamaruensis, Reticulofenestra hillae, and Reticulofenestra umbilica. The presence of these three species limits the age to early Oligocene or older. Because nannofossils are reasonably common and diverse in this sample, the absence of Isthmolithus recurvus, which is common in the subjacent sample (406.57), suggests that the sample is in the Reticulofenestra daviesii Zone of Wei and Wise (1990a), with an age of about 33-34 Ma.

Samples 406.57 and 412.00 contain common $I$. recurvus. This species also occurred in Sample 416.84, 420.25, 664.31, and 681.16. Consequently, the interval from Sample 406.57 to Sample 681.16 can be assigned to the combined Isthmolithus recurvus-Blackites spinosis Zones of Wei and Wise (1990a) based on the stratigraphic range of $I$. recurvus.

The first occurrence (FO) of I. recurvus is also a stratigraphic marker within the late Eocene in the zonations of Martini (1971) and Okada and Bukry (1980), whereas the LO of $I$. recurvus was used in the zonation of Wise (1983). To examine the reliability of the stratigraphic range of $I$. recurvus across latitudes and to estimate the numerical age for the interval from 406.57 to 681.16 mbsf at CIROS-1, a compilation of the stratigraphic range of $I$. recurvus at 11 sites ranging from $43^{\circ} \mathrm{N}$ latitude to $65^{\circ} \mathrm{S}$ latitude is summarized in Figure 3 . It is clear from Figure 3 that the LO of $I$. recurvus does not transgress time across mid to high latitudes. The LO of $I$. recurvus shows a fairly consistent age at about $34.8 \mathrm{Ma}$. The data show a less consistent age for the FO of I. recurvus than for its LO. Figure 3 suggests, however, that the FO of $I$. recurvus is $\sim 39 \mathrm{Ma}$ in age in the southern high latitudes. Isthmolithus recurvus is common from mid to high latitudes, and it shows a fairly consistent age range from $43^{\circ} \mathrm{N}$ to $65^{\circ} \mathrm{S}$. It is reasonable to suggest, therefore, that the stratigraphic range of $I$. recurvus in the CIROS-1 core should be similar to those in Figure $3(\sim 35-39 \mathrm{Ma})$. It is possible, however, that the apparent range of the species at the CIROS-1 site could be shorter because calcareous nannoplankton generally do not thrive in cold waters and nearshore environments, and the high sedimentation rate of clastic sediments at the CIROS-1 site could have diluted the abundance of $I$. recurvus in the sediments to a level below detection.

Other age-diagnostic species present in the 406.57-681.16 mbsf interval include Chiasmolithus oamaruensis (late Eocene-early Oligocene), Reticulofenestra bisecta (middle Eocene-Oligocene), Reticulofenestra daviesii (middle Eocene-Oligocene), and Reticulofenestra hillae (middle Eocene-early Oligocene). All these species are consistent with the late Eocene-earliest Oligocene ( $35-39 \mathrm{Ma})$ age suggested by $I$. recurvus. On the other hand, Chiasmolithussolitus, an early Eocene-middle Eocene coccolith, abundant in deep-sea carbonate ooze surrounding the Antarctic conti-

\begin{tabular}{|c|c|c|c|c|}
\hline Age & $\begin{array}{c}\text { Zones of } \\
\text { Wei and Wise (1990a) }\end{array}$ & Datums & $\begin{array}{l}\text { Zones of Okada } \\
\text { and Bukry (1980) }\end{array}$ & $\begin{array}{c}\text { Zones of } \\
\text { Wise (1983) }\end{array}$ \\
\hline \multirow{3}{*}{ late Oligocene } & \multirow{2}{*}{\multicolumn{2}{|c|}{ No data }} & \multirow{3}{*}{$\begin{array}{l}\text { CP19 } \\
\text { CP18 } \\
\text { CP17 }\end{array}$} & Cyclicargolithus abisectus \\
\hline & & & & Reticulofenestra bisecta \\
\hline & Chiasmolithus altus & Last common Chiasmolithus altus & & Chiasmolithus altus \\
\hline \multirow{3}{*}{ early Oligocene } & Reticulofenestra daviesii & LO Reticulofenestra umbilica & \multirow[b]{2}{*}{ CP16 } & $\begin{array}{l}\text { Reticulofenestra daviesii } \\
\text { Clausicoccus fenestratus }\end{array}$ \\
\hline & Blackites spinosus & LO Isthmolithus recurvus & & Blackites spinosus \\
\hline & Reticulofenestra oamaruensis & enestra oamaruensis & \multirow[b]{2}{*}{ CP15b } & Reticulofenestra oamaruensis \\
\hline \multirow{2}{*}{ late Eocene } & Isthmolithus recurvus & FO Reticulofenestra oamaruensis & & \multirow{3}{*}{ No data } \\
\hline & Chiasmolithus oamaruensis & FO Isthmolithus recurvus & CP15a & \\
\hline \multirow{3}{*}{ middle Eocene } & Discoaster saipanensis & FO Chiasmolithus oamaruensis & $\mathrm{CP} 14 \mathrm{~b}$ & \\
\hline & Reticulofenestra reticulata & LU C niasmontinus solitus & \multirow{2}{*}{$\mathrm{CP} 14 \mathrm{a}$} & \multirow{2}{*}{ Discoaster bifax } \\
\hline & Reticulofenestra umbilica & FO Reticulofenestra reticulata & & \\
\hline
\end{tabular}

Figure 2. The high-latitude nannofossil zonation of Wei and Wise (1990a) used in this study and its correlation with the zonations of Okada and Bukry (1980) and Wise (1983). 
Table 2. Distribution of calcareous nannofossils in the lower sequence of the CIROS-1 core.

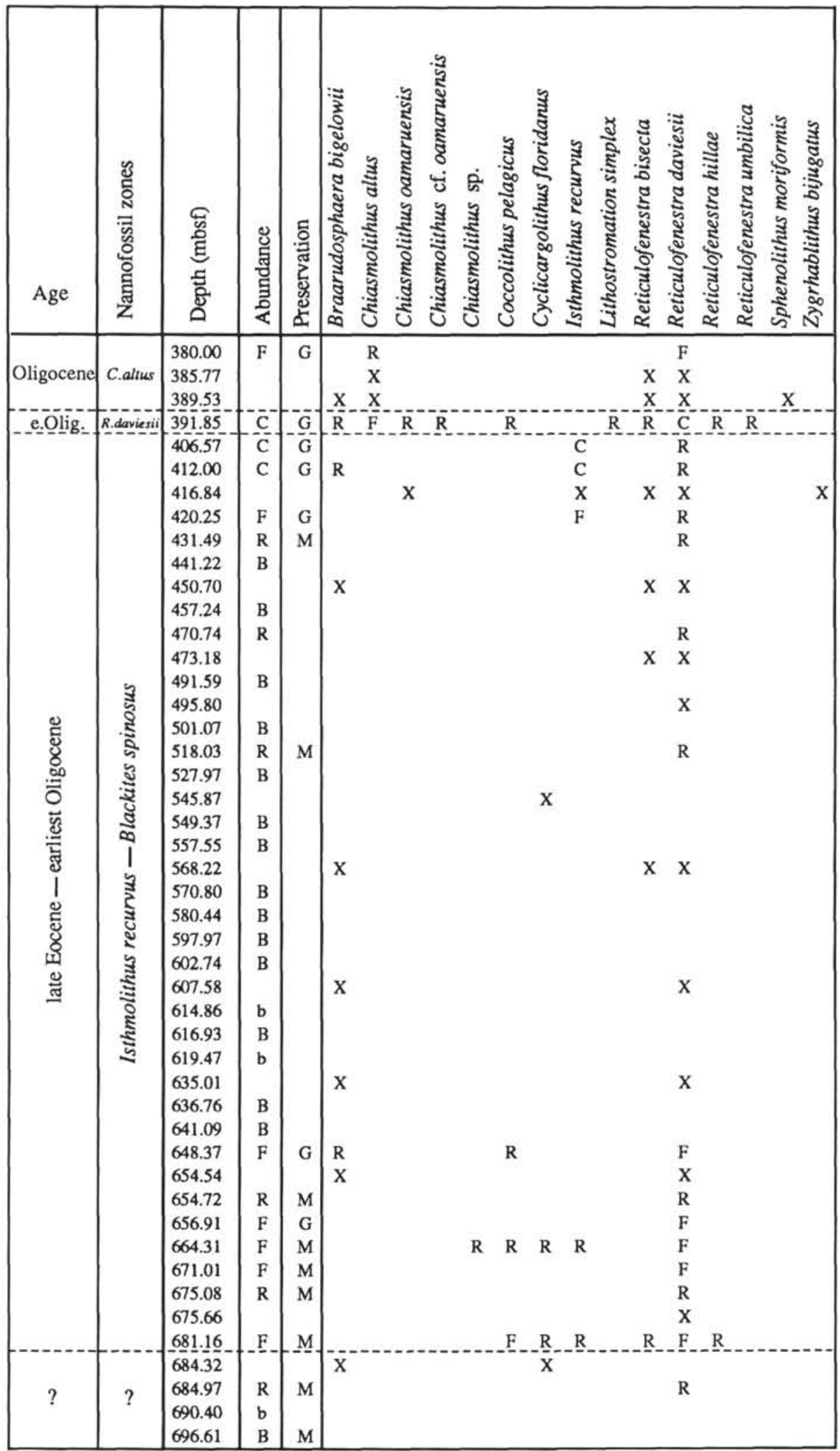

Notes: Nannofossil zones are given according to the southern high-latitude zonation of Wei and Wise (1990a). For abundance of nannofossils, $\mathrm{C}=$ common, $\mathrm{F}=$ few, $\mathrm{R}=$ rare, $\mathrm{B}=$ barren, $\mathrm{X}=$ presence as reported by Edwards and Waghorn (1989), and $b=$ barren as reported by Edwards and Waghorn (1989). For preservation of nannofossils, $\mathrm{G}=$ good and $\mathrm{M}=$ moderate. 


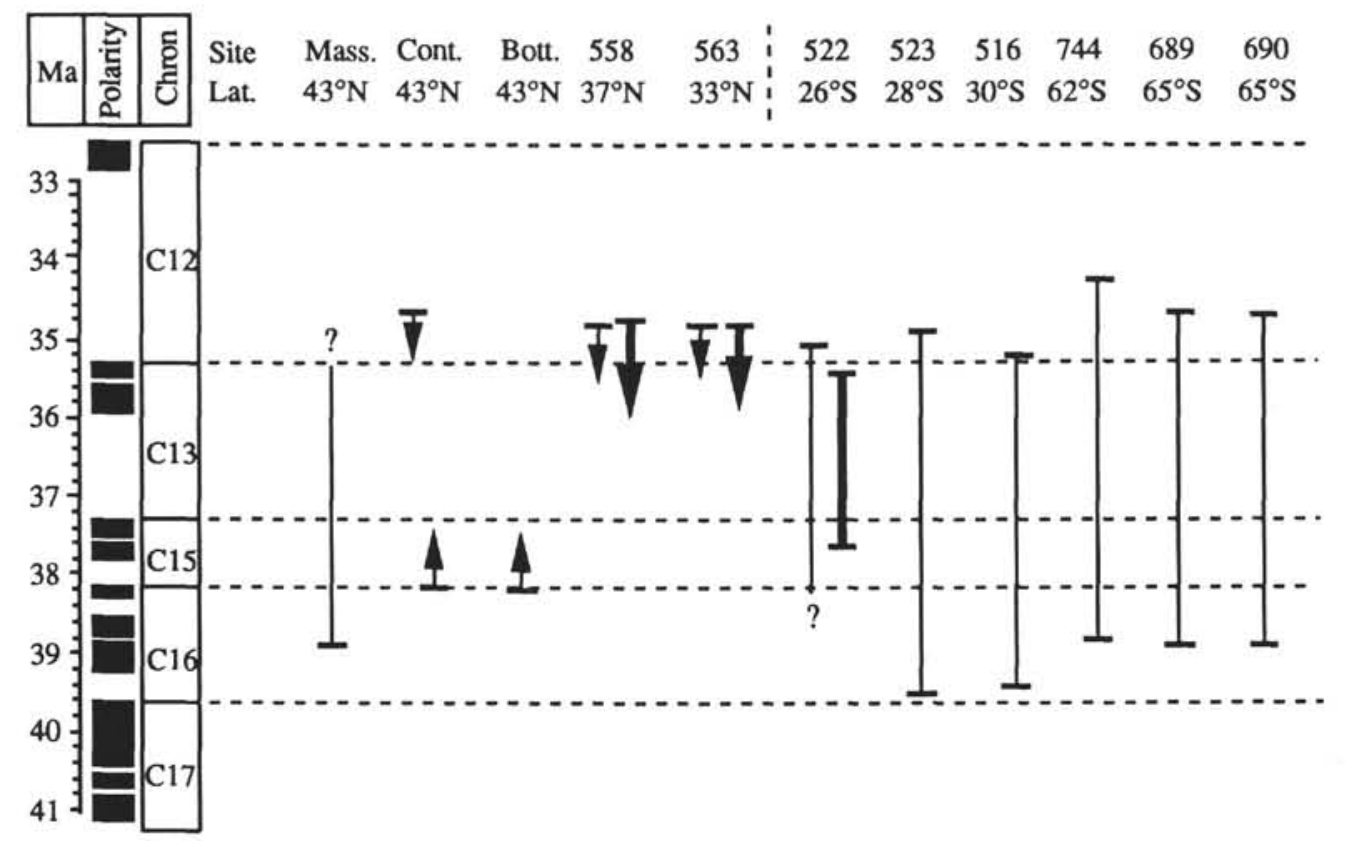

Figure 3. Compilation of biomagnetostratigraphic data of Isthmolithus recurvus across latitudes. Data are taken from Coccioni et al. (1988), Mass. (Massignano, Italy); Monechi and Thierstein (1985), FO at Cont. (Contessa, Italy), Bott. (Bottaccione, Italy); Lowrie et al. (1982), LO at Cont. (Contessa, Italy); Miller et al. (1985), DSDP Sites 558 and 563 (thinner lines); Parker et al. (1985), DSDP Sites 558 and 563 (thicker lines); Backman (1987), DSDP Site 522 (thinner line); Poore et al. (1984), DSDP Site 522 (thicker line), DSDP Site 523; Wei and Wise (1989), DSDP Site 516; Wei and Thierstein (1991), ODP Site 744; Wei and Wise (1990a), ODP Sites 689 and 690. It is estimated from these data that the stratigraphic range of $I$. recurvus at the CIROS-1 site is about $35-39$ Ma or shorter.

nent and apparently present within the Antarctic interior seaways (Wilkes-Pensacola Basins; Wise, 1988), is not present in the CIROS-1 core. This suggests an age younger than middle Eocene for the core. Reticulofenestra reticulata is also absent in the CIROS-1 core. This species is usually abundant in upper Eocene sediments from the southern high latitudes (Wei and Wise, 1990a; Wei and Thierstein, 1991; Wei et al., this volume) and reworked specimens of the species were found in the Prydz Bay sequence (Wei and Thierstein, 1991). The absence of this species in the CIROS-1 core, particularly in those samples $(391.85,664.331$, and 681.16$)$ with diverse nannofossil assemblages, may suggest that the material is younger than $39 \mathrm{Ma}$, an age for the LO of $R$. reticulata at southern high latitudes as calibrated with magnetostratigraphy at ODP Sites 689, 690 (Wei and Wise, 1990a), and 744 (Wei and Thierstein, 1991).

The lowest stratigraphic occurrence of nannofossils in the CIROS-1 core was found in Sample 684.97, in which a few specimens of Reticulofenestra daviesii were present. This species ranges from the middle Eocene to uppermost Oligocene or possibly the lowermost Miocene. No nannofossil zones were assigned to samples below $684.32 \mathrm{mbsf}$ because of the absence of nannofossils or the extremely low species diversities in the basal part of the core.

\section{COMPARISON WITH NANNOFOSSIL ASSEMBLAGES \\ FROM OTHER ANTARCTIC CORES}

It is important to evaluate critically whether the nannofossil assemblages in the CIROS-1 core are reworked or in situ, and to extract some paleoecological information. This can be done by comparing the nannofossil assemblages from the CIROS-1 core, particularly those in Samples 391.85, 664.31, and 681.16 , with those from the southern high latitudes, including those associated with lower Oligocene glacial sediments.

Relative nannofossil species abundances in Section 119744A-16H-7 and Core 119-744A-17H are presented in Figure 4. Coarse sand grains, granules, and a clast believed to be ice-rafted were found within this interval (Barron, Larsen, et al., 1989; Ehrmann, 1991). This ice-rafting interval is dated as $\sim 35.7-36.1$ Ma by biostratigraphic events, strontium isotope, and paleomagnetic data (Fig. 4). The nannofossil assemblage found in this interval consists of Chiasmolithus altus, Coccolithus pelagicus, Isthmolithus recurvus, and four species of Reticulofenestra, a fairly low diversity assemblage.

Nannofossil species abundances for Sections 119-738B$3 \mathrm{H}-4$ and $-3 \mathrm{H}-5$ are shown (Fig. 5). This interval also contains exotic coarse sand-size particles and a pebble interpreted as ice-rafted (Barron, Larsen, et al., 1989; Ehrmann, 1991). The interval contains Isthmolithus recurvus but does not contain Reticulofenestra oamaruensis, and thus has an age older than $34.8 \mathrm{Ma}$ but younger than $36.0 \mathrm{Ma}$. Extrapolation of sedimentation rates from several biostratigraphic datums below suggests an age of about $34.9-35.0 \mathrm{Ma}$. The nannofossil assemblage and the abundances of individual species are virtually the same as at Site 744. The only difference is that Zygrhablithus bijugatus is present in Sections 119-738B-3H-4 and $-3 \mathrm{H}-5$. This species has a very long stratigraphic range $(\mathrm{Pa}-$ leocene through Oligocene), and the main factors in controlling its presence or abundance are probably paleoproductivity and salinity.

A similar glaciomarine sequence as the CIROS-1 core has been recovered at ODP Site 739 in Prydz Bay, East Antarctica (Fig. 1). Calcareous nannofossils are generally rare and occur sporadically in the sequence (Wei and Thierstein, 1991). 


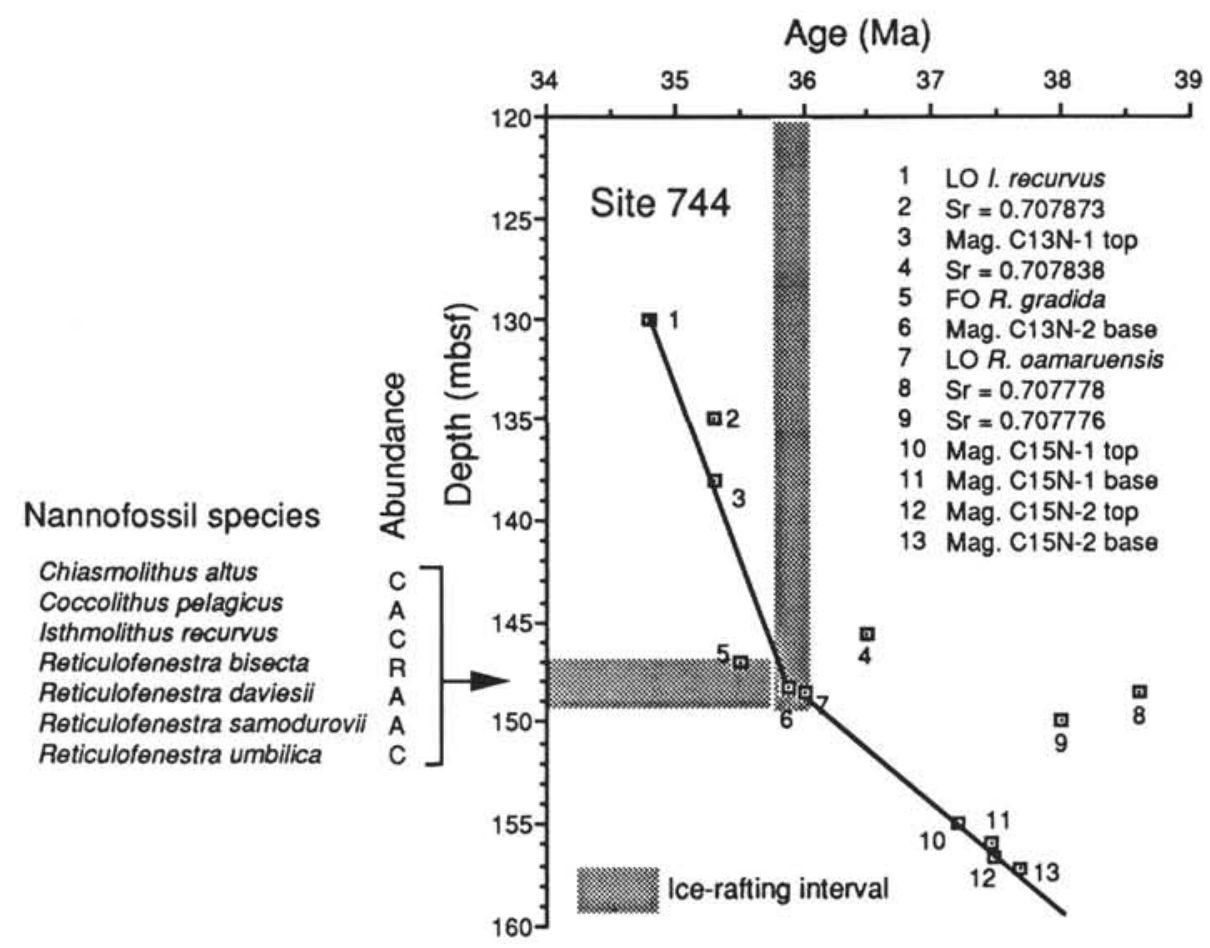

Figure 4. Calcareous nannofossil species abundances in the lower Oligocene ice-rafting interval at Site 744 (Section 119-744A-16H-7 and Core 119-744A-17H). Nannofossil data are taken from Wei and Thierstein (1991). The ice-rafting interval was identified by Barron, Larsen, et al. (1989) and Ehrmann (1991). Refer to Barron et al. (1991) for details of the chemostratigraphic, biostratigraphic, and magnetostratigraphic events used to construct the age-depth curve.

Nevertheless, the nannofossil assemblages from 202.8 and $222.9 \mathrm{mbsf}$ (Fig. 6) are quite age diagnostic, and they constrain the age to late Eocene-earliest Oligocene $(\sim 35-39 \mathrm{Ma})$ based on the presence of Isthmolithus recurvus. This age is consistent with that suggested by the diatom data (early Oligocene; Baldauf and Barron, 1991). Baldauf and Barron (1991) cited evidence that argue for in-situ diatoms in this interval. Although nannofossils are fewer and more sporadic in the diamictite sequence at Site 739 than in the CIROS-1 core, the compositions of the nannofossil assemblages at both sites are virtually the same, with Reticulofenestra daviesii being the most common member of the assemblages. The enrichment of $R$. daviesii in these localities is not unexpected, because a quantitative study of nannofossils by Wei and Wise (1990b) along a latitudinal transect in the South Atlantic Ocean indicated that the species increases in abundance toward higher latitudes.

A comparison of nannofossil species abundances for the Isthmolithus recurvus-Blackites spinosus Zones of Wei and Wise (1990a) at several southern high-latitude sites is summarized in Table 3. Rare Braarudosphaera bigelowii occurred in CIROS-1, Sample 412.00 , but not at other sites. Because this species has a long stratigraphic range (Mesozoic-Cenozoic) and is often related to low-salinity or near-shore environments, the presence of this species in Sample 412.00 does not imply coccolith reworking. In addition, Reticulofenestra hillae was found at Site 739 in a sample from $222.9 \mathrm{mbsf}$, and in CIROS-1, Sample 681.16, but was not recorded at other sites. This species has a smaller central opening than Reticulofenestra umbilica and may be a cooler water form of the latter species, just as Reticulofenestra gelida is a cooler water form of Reticulofenestra pseudoumbilica (the former has a smaller central opening than the latter; see discussion by Backman, 1980).

Other than $B$. bigelowii and $R$. hillae, all the species present at Site 739 and CIROS-1 are present at the deep-sea southern high-latitude sites and have the same relative proportions. The only exceptions are CIROS-1, Samples 406.57 and 412.00 , in which Isthmolithus recurvus dominates the assemblages. Interestingly, this species also dominates the lower Oligocene nannofossil assemblages at ODP Site 696 (Wei and Wise, 1990a) in the Weddell Sea, a shallow-water site (present water depth $=650 \mathrm{~m}$ ). This may indicate that $I$. recurvus was more tolerant of cold waters and nearshore environments than other late Eocene-early Oligocene species. In any event, the enrichment of this species was not caused by dissolution of other nannofossil taxa during reworking, because preservation of the nannofossils is good in those samples.

A comparison of the relative nannofossil species abundance in CIROS-1, Sample 391.85 (Reticulofenestra daviesii Zone of Wei and Wise, 1990a) with those of the same age at Sites 689 and 744 is presented in Table 4. Again, the relative proportions of the species in the CIROS-1 sample are similar to those at the deep-sea sites.

Reticulofenestra hillae and $R$. umbilica were not observed during the previous study of Edwards and Waghorn (1989), who, therefore, suggested biogeographic exclusion of these species from the Antarctic margin. The present study, however, has found these species in the CIROS-1 core (Plate 1, Figs. 19 and 20). Consequently, most of the nannofossil species reported from the deep-sea southern high-latitude sites are also present on the Antarctic continental margin, although their abundances are significantly lower. 


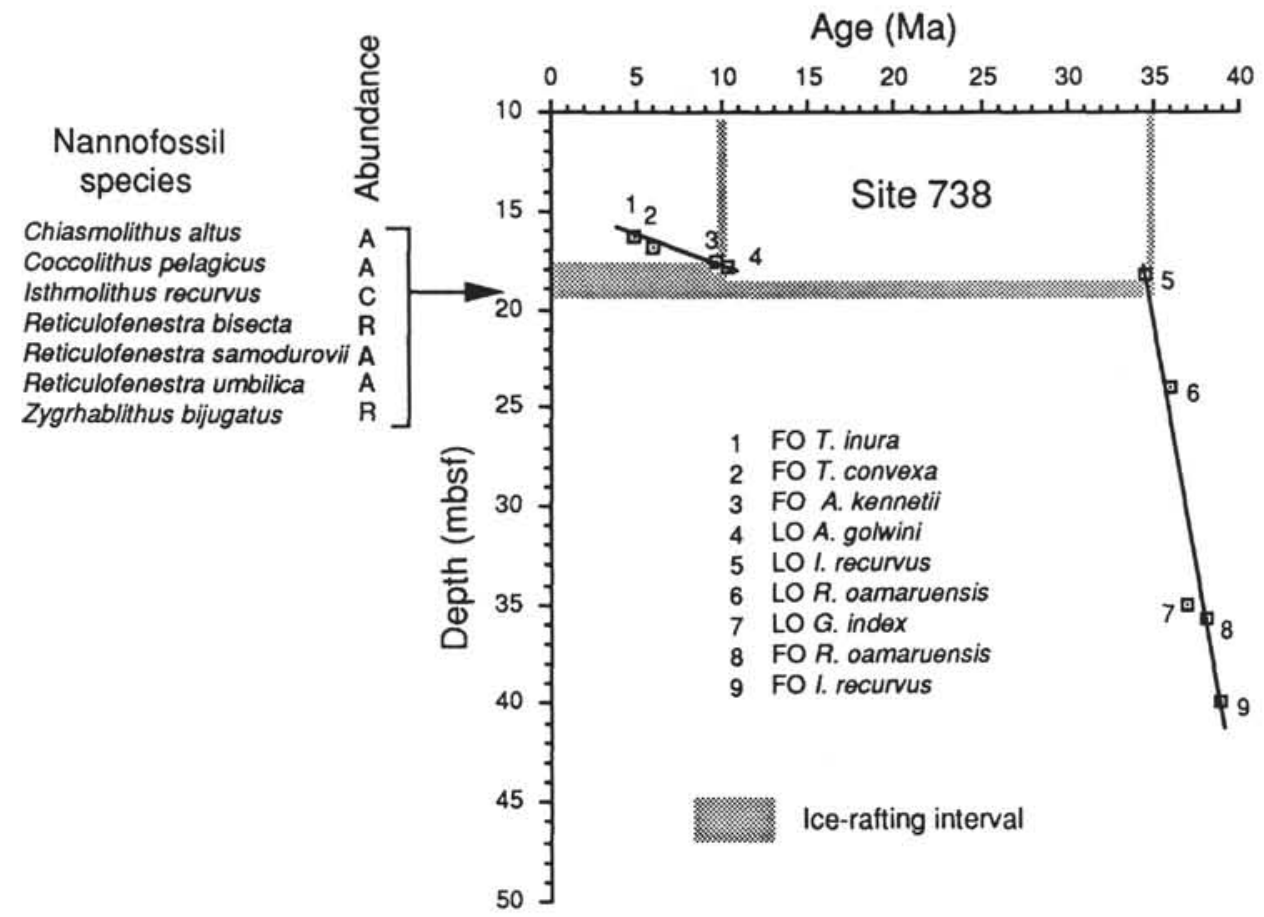

Figure 5. Calcareous nannofossil species abundances in the lower Oligocene ice-rafting interval at Site 738 (Sections 119-738B-3H-4 and -3H-5). Nannofossil data are taken from Wei and Thierstein (1991). The ice-rafting interval was identified by Barron, Larsen, et al. (1989) and Ehrmann (1991). Refer to Barron et al. (1991) for details of the chemostratigraphic, biostratigraphic, and magnetostratigraphic events used to construct the age-depth curve.

In summary, three lines of evidence argue against nannofossil reworking in the CIROS-1 sequence examined, particularly in Samples $391.85,412.00,664.31$, and 681.16 , in which few to common nannofossils were found and the assemblages are fairly diverse:

1. Nannofossil assemblage compositions are similar to those of equivalent ages at the deep-sea southern high-latitude sites and at Site 739 in Prydz Bay.

2. No specimens of lower Paleogene or Mesozoic nannofossils were encountered during this study, nor were they reported in the previous study of Edwards and Waghorn (1989). Species present in the samples are all consistent in age.

3. The nannofossil biostratigraphy is consistent with the biostratigraphy of other fossil groups and with a strontium isotope date at 687.71 mbsf (Harwood et al., 1989).

\section{DISCUSSION}

The nannofossil biostratigraphy of this study for the interval from 406.57 to 681.16 mbsf in CIROS-1 suggests a late Eocene-earliest Oligocene age, consistent with other fossil and strontium data. Consequently, it was in the earliest Oligocene or possibly earlier that the ice front extended at times well beyond that of the present day in the Ross Sea as indicated by the waterlain tills found in the CIROS-1 core. Ice-rafted debris throughout the lower sequence of the CIROS-1 core further show that glaciers were calving at sea level throughout most of the early Oligocene. The CIROS-1 record has provided important information for the Paleogene glacial history of Antarctica.

Other physical evidence for Paleogene glaciation on Antarctica have come mainly from DSDP/ODP drilling. Upper Oligocene glaciomarine sediments were recovered during drilling on Leg 28 at Site 270 in the Ross Sea (Hayes, Frakes, et al., 1975). Ice-rafted debris dated as late early Oligocene at about $33 \mathrm{Ma}$ was also recovered at ODP Site 693 on the slope of the Antarctic continental margin (Barker, Kennett, et al., $1988 ; 1990)$. No basal Oligocene to Upper Cretaceous sediments were recovered at this site because of a major disconformity. Nevertheless, Wise et al. (1987) interpreted the IRD as evidence of an ice sheet on East Antarctica during the early Oligocene.

Lowermost Oligocene IRD have recently been found at ODP Sites 738 (Fig. 5), 744 (Fig. 4), and 748 (Schlich, Wise, et al., 1989; Breza and Wise, this volume) on the Kerguelen Plateau. These IRD so distant from the Antarctic continent (up to $10^{\circ}$ north of the continent) suggest the presence of an Antarctic ice sheet, because mountain icebergs produce glaciers too small to travel long distances from the coast. Only ice sheets can produce bergs large enough to traverse over several degrees of latitude (Mercer, 1973, 1978).

The recent drilling during Leg 119 in Prydz Bay encountered over $100 \mathrm{~m}$ of lower Oligocene diamictites overlying $\sim 200 \mathrm{~m}$ of older diamictites (Fig. 6). These sediments indicate that grounded ice extended at least $140 \mathrm{~km}$ beyond the present ice shelf in Prydz Bay during the earliest Oligocene or possibly as early as the middle Eocene (Leg 119 Shipboard Scientific Party, 1988; Barron, Larsen, et al., 1989, 1991).

Figure 7 (after Wise et al., 1991) summarizes the occurrences of known or suspected Paleogene IRD and glaciomarine sediments. It is clear from Figure 7 that lowermost Oligocene IRD and glaciomarine sediments can be found at both sides of East Antarctica and in different sectors of the Southern Ocean. This suggests that an ice sheet as large as or even larger in extent than the present one existed on Antarctica during the early Oligocene. Before the early Oligocene, 


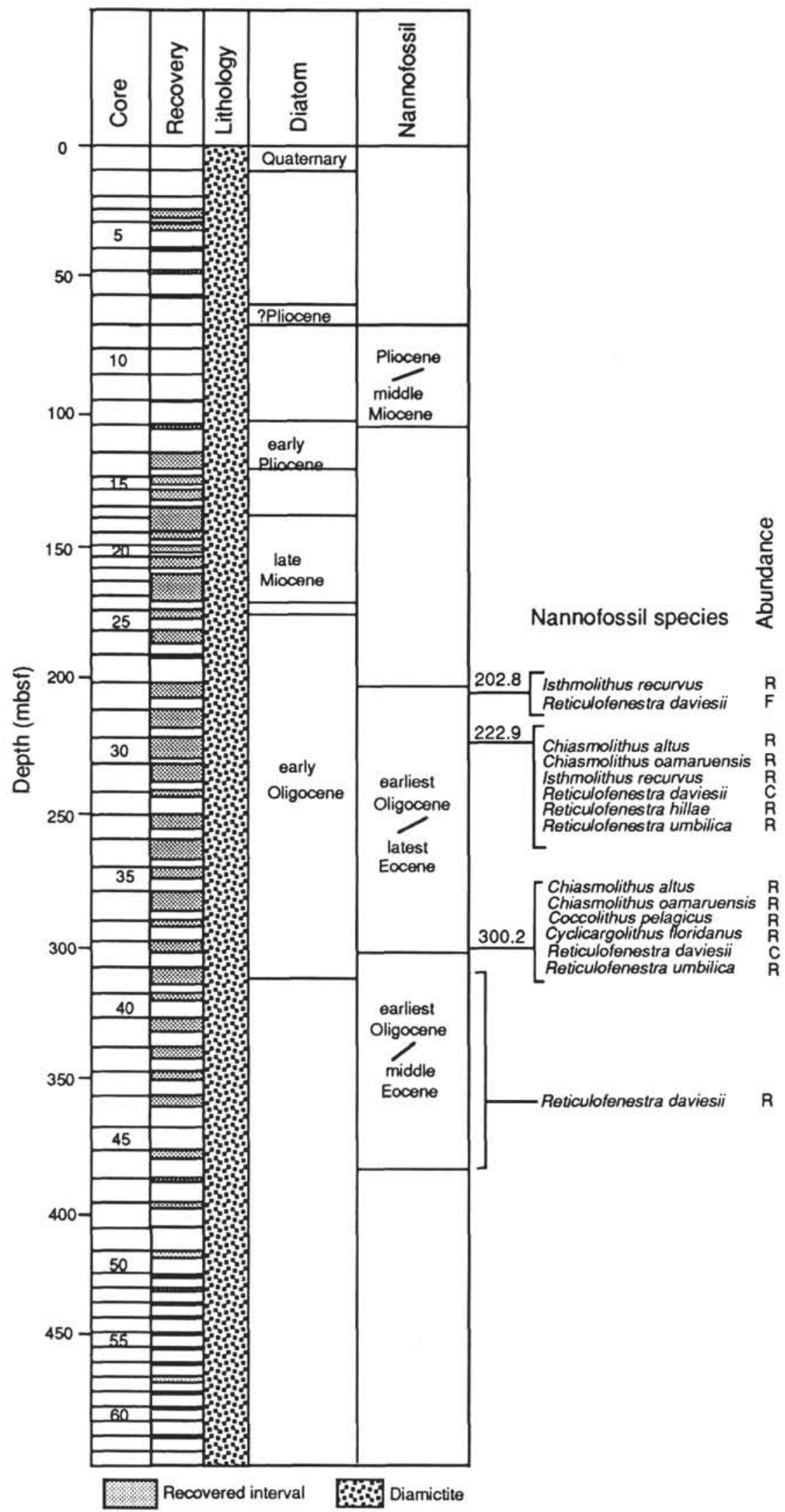

Figure 6. Calcareous nannofossil species abundances at several stratigraphic levels in the upper Eocene-lower Oligocene diamictite sequence recovered at Site 739. Nannofossil data are from Wei and Thierstein (1991), and diatom data are from Baldauf and Barron (1991). 
Table 3. Comparison of nannofossil species abundance data for Isthmolithus recurvus-Blackites spinosus Zones of Wei and Wise (1990a) at several southern high-latitude ODP sites.

\begin{tabular}{|c|c|c|c|c|c|c|c|c|c|}
\hline \multirow{2}{*}{$\begin{array}{c}\text { Site } \\
\text { Sample no. }\end{array}$} & \multirow[t]{2}{*}{744} & \multirow[t]{2}{*}{738} & \multirow[t]{2}{*}{689} & \multicolumn{2}{|c|}{739} & \multicolumn{4}{|c|}{ CIROS-1 } \\
\hline & & & & \#1 & $\# 2$ & \#3 & $\# 4$ & $\# 5$ & \#6 \\
\hline Braarudosphaera bigelowii & & & & & & & $\mathbf{R}$ & & \\
\hline Chiasmolithus altus & A & A & A & & $\mathbf{R}$ & & & ? & \\
\hline Chiasmolithus oamaruensis & $\mathbf{R}$ & $\mathbf{R}$ & $\mathbf{R}$ & & $\mathbf{R}$ & & & & \\
\hline Coccolithus pelagicus & A & A & A & & & & & $\mathbf{R}$ & $\mathrm{F}$ \\
\hline Cyclicargolithus floridanus & $\mathbf{R}$ & $\mathbf{R}$ & & & & & & $\mathbf{R}$ & $\mathbf{R}$ \\
\hline Isthmolithus recurvus & $\mathrm{C}$ & $\mathrm{C}$ & $\mathrm{C}$ & $\mathbf{R}$ & $\mathbf{R}$ & C & C & $\mathrm{R}$ & $\mathbf{R}$ \\
\hline Reticulofenestra bisecta & $\mathrm{F}$ & $\mathrm{F}$ & $\mathrm{F}$ & & & & & & $\mathbf{R}$ \\
\hline $\begin{array}{l}\text { Reticulofenestra daviesii } \\
\text { Reticulofenestra hillae }\end{array}$ & A & A & v & $\mathrm{F}$ & C & $\mathbf{R}$ & $\mathbf{R}$ & $\mathrm{F}$ & F \\
\hline & & & & & $\mathbf{R}$ & & & & $\mathbf{R}$ \\
\hline $\begin{array}{l}\text { Reticulofenestra samodurovii } \\
\text { Reticulofenestra umbilica }\end{array}$ & A & A & A & & & & & & \\
\hline $\begin{array}{l}\text { Reticulofenestra umbilica } \\
\text { Zygrhablithus bijugatus }\end{array}$ & $\begin{array}{l}\mathrm{C} \\
\mathrm{R}\end{array}$ & $\begin{array}{l}\mathrm{C} \\
\mathrm{R}\end{array}$ & $\mathbf{R}$ & & $\begin{array}{l}\mathbf{R} \\
\mathbf{R}\end{array}$ & & & & \\
\hline
\end{tabular}

Notes: Sites are listed according to latitude (higher latitude toward right). Sample numbers are as follows: \#1 = Site 739, 202.8 mbsf; \#2 = Site 739, 222.9 mbsf; \#3 = CIROS-1, 406.57 mbsf; \#4 = CIROS-1, 412.00 mbsf; \#5 = CIROS-1, 664.31; \#6 = CIROS-1, a681.16 mbsf. $\mathrm{A}=$ abundant, $\mathrm{C}=$ common, $\mathrm{F}=\mathrm{few}, \mathrm{V}=$ very few, and $\mathrm{R}=$ rare. The abundance data are taken from the following sources: Wei and Thierstein (1991), Sites 738, 739, and 744; Wei and Wise (1990a), Site 689; and this study, CIROS-1.

Table 4. Comparison of nannofossil species abundance data in CIROS-1 (391.85 mbsf) (Reticulofenestra daviesii Zone of Wei and Wise, 1990a) with those of the same zone at ODP Sites 689 and 744.

\begin{tabular}{|c|c|c|c|}
\hline Site & 744 & 689 & $\begin{array}{c}\text { CIROS-1 } \\
(391.85)\end{array}$ \\
\hline Chiasmolithus altus & A & A & $\mathrm{F}$ \\
\hline Chiasmolithus oamaruensis & & & $\mathbf{R}$ \\
\hline Coccolithus pelagicus & A & $\mathrm{F}$ & $\mathbf{R}$ \\
\hline Cyclicargolithus floridanus & $\mathrm{R}$ & & \\
\hline Lithostromation simplex & & & $\mathbf{R}$ \\
\hline Reticulofenestra bisecta & $\mathbf{F}$ & $\mathbf{F}$ & $\mathbf{R}$ \\
\hline Reticulofenestra daviesii & V & V & C \\
\hline Reticulofenestra hillae & & & $\mathbf{R}$ \\
\hline Reticulofenestra samodurovii & $\mathrm{F}$ & $\mathbf{F}$ & \\
\hline Reticulofenestra umbilica & $\mathbf{R}$ & $\mathbf{R}$ & $\mathbf{R}$ \\
\hline
\end{tabular}

Notes: Sites are listed according to latitude (higher latitude toward right). $\mathrm{A}=$ abundant, $\mathrm{C}=$ common, $\mathrm{F}=$ few, $\mathrm{V}=$ very few, and $\mathrm{R}=$ rare. Abundance data are taken from the following sources: Wei and Thierstein (1991), Site 744; Wei and Wise (1990a), Site 689; and this study, CIROS-1.

smaller ice caps on Antarctica were also possible. Indeed, some evidence to suggest ice caps has been found.

Margolis and Kennett (1971) reported ice-rafted quartz from lower to middle Eocene Eltanin piston cores (13-9, 24-8, 24-9, and 24-10) taken from the southeast Pacific Ocean (Fig. 1). The ages of these cores have now been confirmed and refined by Wei (this volume) using calcareous nannofossil biostratigraphy. Wei (this volume) states that it is unlikely that the quartz grains resulted from downcore contamination, particularly those in Core 24-10, which apparently penetrated no Neogene sediment. He argues in favor of the presence of in-situ quartz grains in these Eocene cores. This would be consistent with the results of Birkenmajer et al. (1986) and Birkenmajer (1987), who reported a fossiliferous tillite in the area of the Krakow Icefield on King George Island of West Antarctica beneath a basaltic lava flow dated as $49.4 \pm 5 \mathrm{Ma}$ (K-Ar date). In addition, Birkenmajer (1987) also reported lower Oligocene and lower Miocene tillites and glaciomarine sediments, indicating multiglacial events considered to be Antarctic-wide.

Even earlier permanent continental glaciers have been suggested. Frakes and Francis (1988) found Lower Cretaceous ice-rafted boulders in central Australia, which indicate glacial activity during one of the warmest periods in the Phanerozoic. Compiling data on ice-rafted deposits in different parts of the world for the Phanerozoic led Frakes and Francis (1988) to conclude that the possibility of an ice-free Earth having ever existed appears small.

\section{CONCLUSIONS}

This study has refined the nannofossil biostratigraphy of the CIROS-1 core and dated sediment from 391.85 mbsf as early Oligocene ( $\sim 33-34 \mathrm{Ma})$ in the Reticulofenestra daviesii Zone of Wei and Wise (1990a), and the interval from 406.95 to $681.16 \mathrm{mbsf}$ as late Eocene-earliest Oligocene ( $35-39 \mathrm{Ma})$ in the Isthmolithus recurvus-Blackites spinosus Zones of Wei and Wise (1990a). These ages are consistent with the biostratigraphy of other fossil groups and with a strontium isotope date at 687.71 mbsf (Harwood et al., 1989). Consequently, it was in the earliest Oligocene or possibly earlier that the ice front extended at times well beyond that of the present day in the Ross Sea, as indicated by the waterlain tills at the CIROS-1 site. This, together with the glacial evidence from Site 748 and other Southern Ocean sites, clearly suggests the existence of an earliest Oligocene ice sheet on Antarctica.

Semiquantitative nannofossil data from CIROS-1 indicate that the nannofossil assemblages are similar to those in Prydz Bay and those of an equivalent age at deep-sea southern high-latitude Sites 738 and 744 in which lowermost Oligocene IRD were found. No specimens of lower Paleogene or Mesozoic nannofossils were encountered in the CIROS-1 core. Furthermore, the nannofossil biostratigraphy is consistent with those of other fossil groups. All these findings argue against nannofossil reworking in the samples examined.

The semiquantitative nannofossil data suggest that Isthmolithus recurvus and Reticulofenestra daviesii are most tolerant of cold waters relative to other late Eocene-early Oligocene calcareous nannofossil species. 


\begin{tabular}{|c|c|c|c|c|c|c|c|c|c|c|c|c|c|c|c|}
\hline \multirow{2}{*}{$\frac{\text { Region }}{\text { Site }}$} & \multicolumn{3}{|c|}{ Ross Sea } & \multirow{2}{*}{\begin{tabular}{|c|}
$\begin{array}{c}\text { Marie } \\
\text { Byrd Land }\end{array}$ \\
$\begin{array}{c}\text { Mt. } \\
\text { Petras }\end{array}$ \\
\end{tabular}} & \multirow{2}{*}{$\begin{array}{c}\text { Weddell } \\
\text { Sea }\end{array}$} & \multicolumn{2}{|c|}{$\begin{array}{l}\text { Prydz } \\
\text { Bay }\end{array}$} & \multicolumn{3}{|c|}{$\begin{array}{l}\text { Kerguelen } \\
\text { Plateau }\end{array}$} & \multirow{2}{*}{\begin{tabular}{|c|} 
Antarctic \\
Peninsula \\
King \\
George \\
Island \\
\end{tabular}} & \multicolumn{4}{|c|}{ Southeast Pacific } \\
\hline & $\begin{array}{c}\text { DSDP } \\
270\end{array}$ & MSSTS-1 & CIROS-1 & & & $\begin{array}{l}\text { ODP } \\
739 \\
\end{array}$ & $\begin{array}{l}\text { ODP } \\
742 \\
\end{array}$ & $\begin{array}{l}\text { ODP } \\
738 \\
\end{array}$ & $\begin{array}{l}\text { ODP } \\
744\end{array}$ & $\begin{array}{l}\text { ODP } \\
748\end{array}$ & & $\begin{array}{c}\text { Eltanin } \\
13-4 \\
\end{array}$ & $\begin{array}{c}\text { Eltanin } \\
24-8\end{array}$ & $\begin{array}{c}\text { Eltanin } \\
24-9 \\
\end{array}$ & $\begin{array}{r}\text { Eltanin } \\
24-10 \\
\end{array}$ \\
\hline Latitude & $77^{\circ} \mathrm{S}$ & $78^{\circ} \mathrm{S}$ & $77^{\circ} \mathrm{S}$ & $76^{\circ} \mathrm{S}$ & $71^{\circ} \mathrm{S}$ & $67^{\circ} \mathrm{S}$ & $67^{\circ} \mathrm{S}$ & $63^{\circ} \mathrm{S}$ & $62^{\circ} \mathrm{S}$ & $58^{\circ} \mathrm{S}$ & $62^{\circ} \mathrm{S}$ & $58^{\circ} \mathrm{S}$ & $43^{\circ} \mathrm{S}$ & $41^{\circ} \mathrm{S}$ & $38^{\circ} \mathrm{S}$ \\
\hline
\end{tabular}

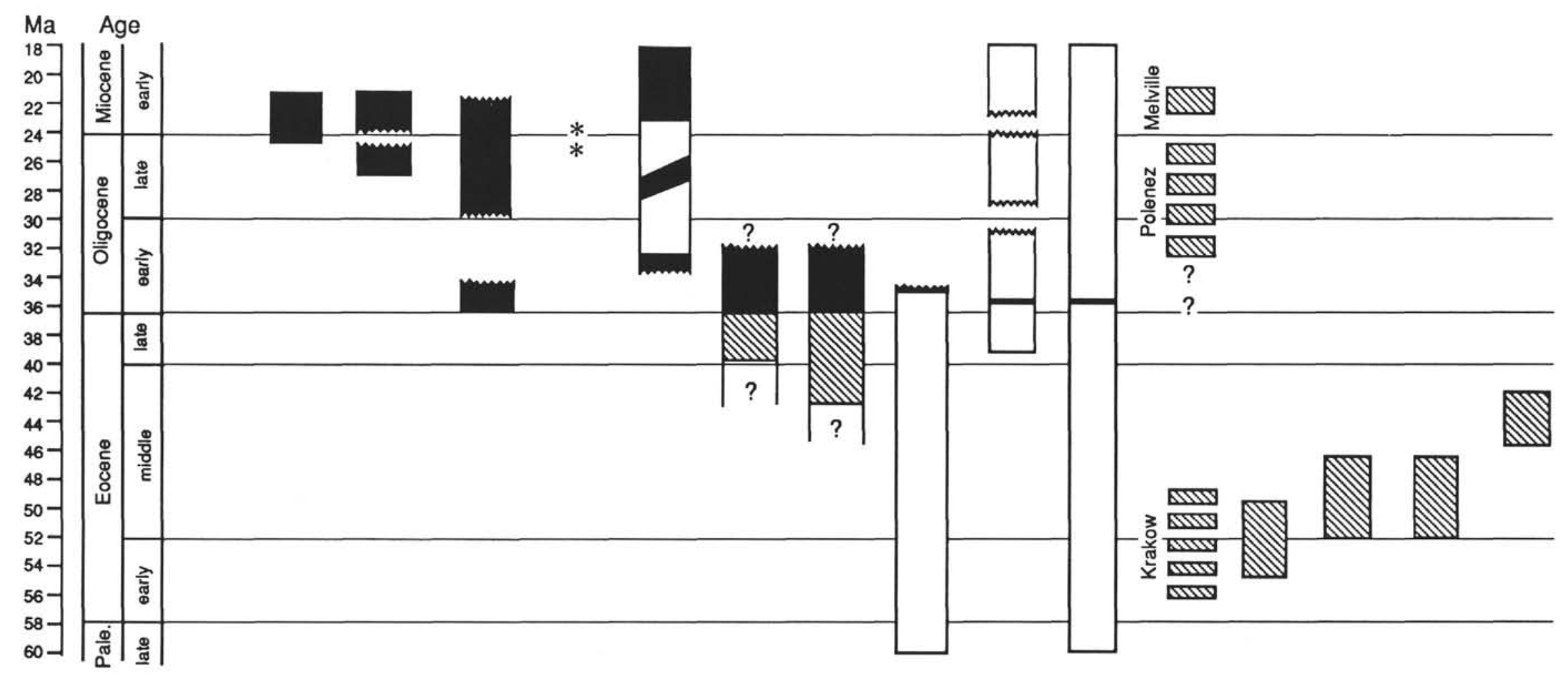

Reported glacial/glaciomarine sediment
well documented and dated Reported glacial/glaciomarine sediment $\begin{aligned} & \text { Ress well documented and/or dated } \\ & \text { led }\end{aligned}$ misconformity Hyaloclastite

Figure 7. Occurrences of known or suspected Paleogene IRD and glaciomarine sediments (after Wise et al., 1991). 


\section{ACKNOWLEDGMENTS}

The CIROS project was a New Zealand Antarctic research program conducted jointly by Antarctic Division, Department of Scientific and Industrial Research (New Zealand), and the Victoria University of Wellington's Antarctic Research Centre, with United States interests coordinated through Ohio State University. I wish to thank Mr. D. Cassidy, Curator of Florida State University's Antarctic Research Facility, for supplying the samples and providing helpful literature references. I am particularly grateful to Professor S. W. Wise for his interest in this and other studies and for his invitation to submit this manuscript to Proceedings of Ocean Drilling Program, Scientific Results, Volume 120. He also read an early draft of this manuscript and provided many helpful suggestions. I would also like to thank Dr. R. E. Constans (Chevron) and an anonymous reviewer for extremely constructive reviews. This study was supported by an equipment grant from the Amoco Foundation and an NSF Grant DPP8917976 to S. W. Wise.

\section{REFERENCES}

Backman, J., 1980. Miocene-Pliocene nannofossils and sedimentation rates in the Hatton-Rockall Basin, NE Atlantic Ocean. Stockholm Contrib. Geol., 36:1-91.

1987. Quantitative calcareous nannofossil biochronology of middle Eocene through early Oligocene sediment from DSDP Sites 522 and 523. Abh. Geol. Bundensanst.-Austria, 39:21-31.

Baldauf, J. G., and Barron, J. A., 1991. Diatom biostratigraphy: Kerguelen Plateau and Prydz Bay regions of the Southern Ocean. In Barron, J. A., Larsen, B., et al., Proc. ODP, Sci. Results, 119: College Station, TX (Ocean Drilling Program), 000-000.

Barker, P. F., Kennett, J. P., et al., 1988. Proc. ODP, Init. Repts., 113: College Station, TX (Ocean Drilling Program).

1990. Proc. ODP, Sci. Results, 113: College Station, TX (Ocean Drilling Program).

Barrett, P. J., Hambrey, M. J., Harwood, D. M., Pyne, A. R., and Webb, P.-N., 1989. Synthesis. In Barrett, P. J. (Ed.), Antarctic Cenozoic History from CIROS-1 Drillhole McMurdo Sound, Department of Scientific and Industrial Research Bulletin (New Zealand), 245:241-251.

Barron, J. A., Baldauf, J. G., Barrera, E., Caulet, J.-P., Huber, B. T., Keating, B. H., Lazarus, D., Sakai, H., Thierstein, H. R., and Wei, W., 1991. Biochronologic and magnetochronologic synthesis of Leg 119 sediments from the Kerguelen Plateau and Prydz Bay, Antarctica. In Barron, J. A., Larsen, B., et al., Proc. ODP, Sci. Results, 119: College Station, TX (Ocean Drilling Program).

Barron, J. A., Larsen, B., et al., 1989. Proc. ODP, Init. Repts., 119: College Station, TX (Ocean Drilling Program).

1991. Proc. ODP, Sci. Results, 119: College Station, TX (Ocean Drilling Program).

Birkenmajer, K., 1987. Tertiary glaciation in the South Shetland Island, West Antarctica: evaluation of data. 5th Int. Symp. Antarctic Earth Sci., Cambridge, August 1987, p. 16. (Abstract)

Birkenmajer, K., Delitata, M. C., Narebski, W., Nicoletti, M., and Petrucciani, C., 1986. Geochronology of Tertiary island-arc volcanics and glacigenic deposits, King George Island, South Shetland Islands (West Antarctica). Bull. Polish Acad. Sci., Earth Sci., 34:257-273.

Coccioni, R., Monaco, P., Monechi, S., Nocchi, M., and Parisi, G., 1988. Biostratigraphy of the Eocene-Oligocene boundary at Massignano (Ancona, Italy). In Premoli Silva, I., Coccioni, R., and Montanari, A. (Eds.), The Eocene/Oligocene Boundary in the Marche-Umbria Basin (Italy): Ancona (Industrie Grafiche Filli Aniballi), 59-80.

Edwards, A. R., and Waghorn, D. B., 1989. Calcareous nannofossils. In Barrett, P. J. (Ed.), Antarctic Cenozoic History from the CIROS-1 Drillhole, McMurdo Sound. DSIR Bulletin, 245:145149.

Ehrmann, W. U., 1991. Sediment composition on southern Kerguelen Plateau and its implications for paleoclimate and depositional environment. In Barron, J. A., Larsen, B., et al., 1989. Proc. ODP, Sci. Results, 119: College Station, TX (Ocean Drilling Program).

Frakes, L. A., and Francis, J. E., 1988. A guide to Phanerozoic cold polar climates from high-latitude ice-rafting in the Cretaceous. Nature, 333:547-549.

Hambry, M. J., Barrett, P. J., and Robinson, P. H., 1989. Stratigraphy. In Barrett, P. J. (Ed.), Antarctic Cenozoic History from CIROS-1 Drillhole McMurdo Sound. DSIR Bulletin, 245:23-48.

Harwood, D. M., Barrett, P. J., Edwards, A. R., Rieck, J. J., and Webb, P.-N., 1989. Biostratigraphy and chronology. In Barrett, P. J. (Ed.), Antarctic Cenozoic History from CIROS-I Drillhole McMurdo Sound. DSIR Bulletin, 245:231-239.

Hayes, D. E., Frakes, L. A., et al., 1975. Init. Repts. DSDP, 28: Washington (U.S. Govt. Printing Office).

Leg 119 Shipboard Scientific Party, 1988. Early glaciation of Antarctica. Nature, 333:303-304.

Lowrie, W., Alvarez, W., Napoleone, G., Perch-Nielsen, K., Premoli Silva, I., and Toumarkine, M., 1982. Paleogene magnetic stratig. raphy in Umbrian pelagic carbonate rocks: the Contessa sections, Gubbio. Geol. Soc. Am. Bull., 93:414-432.

Margolis, S. V., and Kennett, J. P., 1971. Cenozoic glacial history of Antarctica recorded in subantarctic deep-sea cores. Am. J. Sci., 271:1-36.

Martini, E., 1971. Standard Tertiary and Quaternary calcareous nannoplankton zonation. In Farinacci, A. (Ed.), Proceedings of the Second International Conference on Planktonic Microfossils, Roma, 1970: Rome (Ed. Technoscienza), 2:739-785.

Mercer, J. H., 1973. Cainozoic temperature trends in the Southern Hemisphere: Antarctic and Andean glacial evidence. In van Zinderen Bakker, E. M. (Ed.), Paleoecology of Africa and of the Surrounding Islands and Antarctica: Cape Town (Balkema), 85114.

1978. Glacial development and temperature trends in the Antarctic and in South America. In van Zinderen Bakker, E. M. (Ed.), Antarctic Glacial History and World Palaeoenvironments: Rotterdam (Balkema), 73-93.

Miller, K. G., Aubry, M.-P., Khan, M. J., Melillo, A. J., Kent, D. V., and Berggren, W. A., 1985. Oligocene-Miocene biostratigraphy, magnetostratigraphy, and isotopic stratigraphy of the western North Atlantic. Geology, 13:257-261

Monechi, S., and Thierstein, H. R., 1985. Late Cretaceous-Eocene nannofossil and magnetostratigraphic correlations near Gubbio, Italy. Mar. Micropaleontol., 9:419-440.

Okada, H., and Bukry, D., 1980. Supplementary modification and introduction of code numbers to the low-latitude coccolith biostratigraphic zonation (Bukry, 1973; 1975). Mar. Micropaleontol., $5: 321-325$.

Parker, M. E., Clark, M., and Wise, S. W., Jr., 1985. Calcareous nannofossils of Deep Sea Drilling Project Sites 558 and 563, North Atlantic Ocean: biostratigraphy and the distribution of Oligocene braarudosphaerids. In Bougault, H., Cande, S. C., et al., Init. Repts. DSDP, 82: Washington (U.S. Govt. Printing Office), 559589.

Perch-Nielsen, K., 1985. Cenozoic calcareous nannofossils. In Bolli, H. M., Saunders, J. B., and Perch-Nielsen, K., (Eds.), Plankton Stratigraphy: Cambridge (Cambridge Univ. Press), 427-554.

Poore, R. Z., Tauxe, L., Percival, S. F., Jr., LaBrecque, J. L., Wright, R., Petersen, N. P., Smith, C. C., Tucher, P., and Hsü, K. J., 1984. Late Cretaceous-Cenozoic magnetostratigraphic and biostratigraphic correlations for the South Atlantic Ocean, Deep Sea Drilling Project Leg 73. In Hsü, K. J., LaBrecque, J., et al., Init. Repts. DSDP, 73: Washington (U.S. Govt. Printing Office), 645-655.

Robinson, P. H., Pyne, A. R., Hambrey, M. J., Hall, K. J., and Barrett, P. J., 1987. Core log, photographs and grain size analyses from the CIROS-1 drillhole, western McMurdo Sound, Antarctic. Antarctic Data Series No. 14, Victoria University of Wellington, 1-241.

Schlich, R., Wise, S. W., Jr., et al., 1989. Proc. ODP, Init. Repts., 120: College Station, TX (Ocean Drilling Program).

Wei, W., and Thierstein, H. R., 1991. Upper Cretaceous and Cenozoic calcareous nannofossils of the Kerguelen Plateau (southern Indian Ocean) and Prydz Bay (East Antarctica). In Barron, J. A., 
Larsen, B., et al., Proc. ODP, Sci. Results, 119: College Station, TX (Ocean Drilling Program).

Wei, W., and Wise, S. W., Jr., 1989. Paleogene calcareous nannofossil magnetobiochronology: results from South Atlantic DSDP Site 516. Mar. Micropaleontol., 14:119-152.

1990a. Middle Eocene to Pleistocene calcareous nannofossils recovered by Ocean Drilling Program Leg 113 from the Weddell Sea. In Barker, P. F., Kennett, J. P., et al., Proc. ODP, Sci. Results, 113: College Station, TX (Ocean Drilling Program), 639-666.

, 1990b. Middle Eocene-Oligocene calcareous nannoplankton biogeographic gradient of the South Atlantic Ocean. Palaeogeogr., Palaeoclimatol., Palaeoecol., 79:29-61.

Wise, S. W., Jr., 1983. Mesozoic and Cenozoic calcareous nannofossils recovered by Deep Sea Drilling Project Leg 71 in the Falkland Plateau region, Southwest Atlantic Ocean. In Lugwig, W. J., Krasheninnikov, V. A., et al., Init. Repts. DSDP, 71: Washington (U.S. Govt. Printing Office), 481-550.

1988. Mesozoic-Cenozoic history of calcareous nannofossils in the region of the Southern Ocean. Palaeogeogr., Palaeoclimatol., Palaeoecol., 67:157-179.
Wise, S. W., Jr., Breza, J. R., Harwood, D. M., and Wei, W., 1991. Paleogene glacial history of Antarctica. In Müller, D. W., McKenzie, J. A., and Weissert, H. (Eds.), Controversies in Modern Geology: London (Academic Press), 133-171.

Wise, S. W., Jr., Hay, W. W., O'Connell, S., Barker, P. F., Kennett, J. P., Burckle, L. H., Egeberg, P. K., Fütterer, D. K., Gersonde, R. E., Golovchencko, X., Hamilton, N., Lazarus, D. B., Mohr, B., Nagao, T., Pereira, C.P.G., Pudsey, C. J., Robert, C. M., Schlandl, E., Spiess, V., Stott, L. D., Thomas, E., and Thompson, K.F.M., 1987. Early Oligocene ice on the Antarctic continent. Geol. Soc. Am., Abstr. Programs, 19:893.

Date of initial receipt: 26 February 1990

Date of acceptance: 5 August 1990

Ms 120B-197 

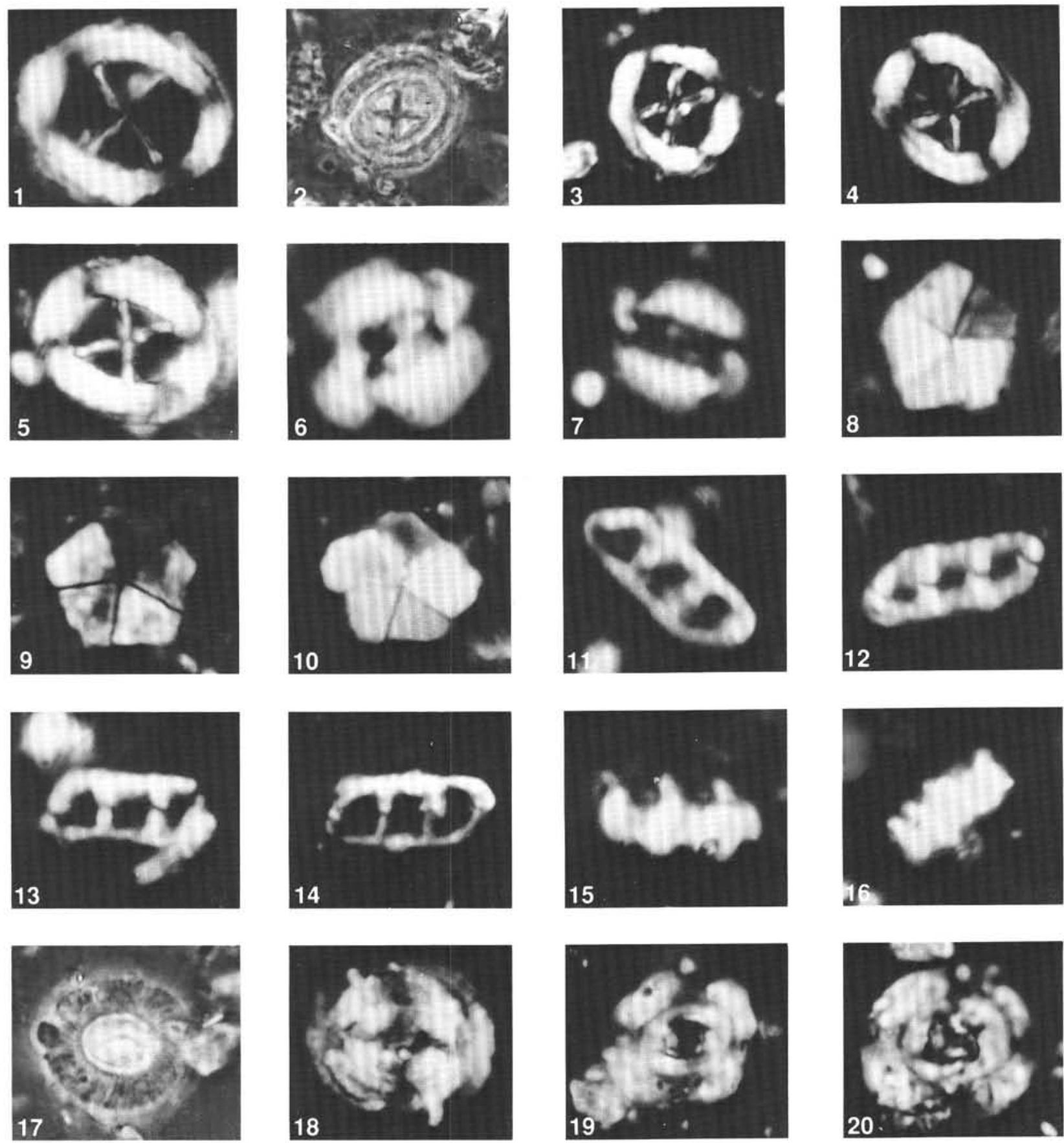

Plate 1. Calcareous nannofossils from the basal $320-\mathrm{m}$ sequence of the CIROS-1 core. All specimens were photographed under cross-polarized light, except (2) and (17), which were photographed under phase-contrast light. 1-10. From 391.85 mbsf; (1-2), Chiasmolithus altus, $\times 2,700$; (3), Chiasmolithus oamaruensis, $\times 2,200$; (4 and 5), Chiasmolithus $\mathrm{cf}$. C. oamaruensis, $\times 2,200$; ( 6 and 7), Reticulofenestra daviesii, $\times 3,300$; (8-10), Braarudosphaera bigelowii, $\times 2,200$. 11-16, Isthmolithus recurvus, $\times 2,750$; (11-13), from $406.57 \mathrm{mbsf}$; (14-15), from 412.00 mbsf; (16), from 664.31. 17-18. Coccolithus pelagicus, $\times 2,750$, from 391.85 mbsf. 19-20. Reticulofenestra hillae, $\times 1,500$, from $391.85 \mathrm{mbsf}$. 